\title{
ARMA DE FOGO: DA CONTRAVENÇÃO AO CRIME
}

\author{
José Orsomarzo Neto \\ Doutorando em Direito Penal pela Faculdade de Direito da \\ Universidade de São Paulo; Delegado da Polícia Federal e advogado \\ em São Paulo.
}

\begin{abstract}
Resumo:
O autor aborda os arts. 18, 19 e 28 da Lei de Contravenções Penais; a Lei do Registro e porte de armas de fogo, através de suas regulamentações específicas, com conclusões pessoais desta exposição de motivos.
\end{abstract}

\section{Abstract:}

The author approaches arts. 18, 19 and 28 of the Law of Criminal Contraventions; the Law of the Register and transport of firearms, through its specific regulations, with personal conclusions of this display of reasons.

Unitermos: crimes cometidos com armas de fogo; aumento de criminalidade; desarmamento da população.

Sumário:

I - Introdução;

II O art. 18 da Lei das Contravenções Penais;

III O art. 19 da Lei de Contravenções Penais;

IV - O art. 28 da Lei de Contravenções Penais;

V - A Lei do Registro e Porte de Arma de Fogo;

VI Regulamentação da Lei;

VII - Conclusão;

Bibliografia.

I. Introdução

Com as mudanças sociais ocorridas a partir da década de 70 , houve um notável aumento da criminalidade, especialmente no que diz respeito aos crimes de 
maior gravidade, cujo emprego de violência, sempre esteve aliado ao uso indevido de armas de fogo e porque não das chamadas "armas brancas"

Com a alta sofisticação tecnológica alcançada em todas as áreas do conhecimento humano, inegavelmente as armas de fogo (revólveres, pistolas e outras) se transformaram em verdadeiras armas de guerra ou armas de ataque, em lugar dos comedidos armamentos antigos (garruchas, revólveres e pistolas de pequenos calibres) com capacidade de disparos também regular e não com o "plus" atual.

Assim nada mais restou ao Governo Federal, no intuito de aperfeiçoal ou procurar atualizar a legislação, editar a Lei n. $9.437 / 97$, de 20/02/97, elevando o porte de arma à categoria de crime e ampliando as condutas passíveis de punição, muitas delas idênticas ao tráfico de entorpecentes, regulamentada pelo Decreto n. 2.222/97.

Destarte, nos propomos a um estudo comparativo entre as contravenções previstas nos arts. 18, 19 e 28 e o crime previsto na lei nova, levantando ainda a atual conjuntura social, bem diferente da época em que foi editada a Lei de Contravenções Penais (1941), informando, ainda, sobre casos ou práticas em que a arma de fogo serviu como defesa ao usuário e em outros não, finalizando conclusivamente com a adesão à recente Súmula n. 174 do Pretório Excelso e opinião pessoal sobre o tema, hoje objeto de grandes comentários e apreciações no meio sócio-jurídico, visto a proteção e salvaguarda do bem jurídico de maior valor que é a Vida Humana.

\section{II. $\mathrm{O}$ art. 18 da Lei das Contravenções Penais}

$\mathrm{O}$ art. em questão possui múltiplas ações físicas, que assim se definem:

a. Fabricar - está relacionado à produção ou criação;

b. Importar - tem o sentido de trazer de um país para outro;

c. Exportar significa o oposto de importar, ou seja, remeter para o

Exterior;

d. Ter em depósito é o caso de retenção ou conservação de armas ou munições;

e. Vender - é o ato de dispor ou alienar coisa própria mediante pagamento de preço.

Neste artigo somente são consideradas as chamadas armas próprias (revólver, espingarda, pistola).

A munição vem a ser o material próprio para que se efetue a carga e o disparo da arma. 
Todos os atos previstos neste artigo são objetos de regulamentação e serão caracterizadas as condutas, quando efetuadas sem permissão da autoridade.

São infrações de mera conduta, havendo previsão legal na Lei de Segurança Nacional (Lei n. 7.170/83), quando atentar contra a ordem política ou social do Estado.

A jurisprudência tem entendido que:

"O art. 18 da LCP incrimina o fato de o agente ter armas ou munições em depósito, para fim.de comércio, sem licença da autoridade, e não tê-las guardadas para seu uso (RT 13/263)"

"Não é possível interpretar extensivamente a lei penal. Se o texto do art. 18 da LCP refere-se ao comércio e ao fabrico, não há com tal se confundir uma simples venda, de uma única arma (RT 395/305)"

III. O art. 19 da lei de Contravenções Penais

O conceito doutrinário do dispositivo legal é no sentido de que o porte ilegal de arma, a guarda ilegal ou descuidada de arma ou de munição, oferecem perigo à pessoa.

Com efeito o indivíduo que porta uma arma sem autorização legal, presumivelmente demonstra uma predisposição para o cometimento de um mal maior, no caso um crime.

Os doutrinadores em linhas gerais conceituam arma como: "o objeto ou utensílio que sirva para matar, ferir ou ameaçar, seja qual for a forma ou seu destino principal" (Manoel Pedro Pimentel, Contravenções Penais, RT, SP, 1975, pp. 113114).

Existem armas próprias (revólveres, punhais) e as armas impróprias (foice, machado, martelo) que, na verdade, são utensílios.

Outra distinção existente são as armas de uso permitido e as armas de uso proibido ou restrito.

Os elementos da contravenção estão expostos da seguinte forma: "trazer consigo a arma", "fora de casa ou de dependência dela" inexistência de licença da autoridade competente.

Para a elucidação de tais elementos trazemos à colação a seguinte ementa: " a contravenção do art. 19 da respectiva lei consiste na apresentação com a arma em estado de pronto uso, fora de casa e sem licença de autoridade” (RT 435/352). 
Tem-se em vista a proteção da vida e integridade física da pessoa humana, em caráter preventivo, digamos até como uma forma de segurança física individual.

Qualquer pessoa pode ser sujeito ativo ou passivo, sendo que o primeiro deverá ter 18 anos e capaz.

As armas próprias são objeto material da contravenção, o que não acontece com as impróprias, porém as armas brancas são proibidas, a exceção como instrumento de trabalho (facas dos açougueiros, peixeiros).

A diferença entre porte e transporte é essencial na tipificação da conduta, como fixado em Acórdão do STF: "Não constitui infração punível, o transporte de arma em envoltório impeditivo de uso nocente e imediato"

Para os autores a distinção deve se ater à condição de pronto uso, como na seguinte decisão: "o que caracteriza o porte de arma, distinguindo-o do meio de transporte, é a circunstância de tê-la o agente em condições de uso fácil e rápido" (RT 438/479).

Há também jurisprudência no sentido de que o automóvel na via pública não é extensão da casa, assim como o bar também não o é, embora esta não seja pacífica.

O elemento subjetivo que caracteriza a contravenção é a voluntariedade, ou seja, a vontade do agente de andar armado, aumentando suas possibilidades de ataque e defesa.

No $§ 1^{\circ}$, é prevista a agravação da pena em razão de sentença irrecorrível por violência contra a pessoa, não importando se é crime ou contravenção.

Nas alîneas do $§ 2^{\circ}$, são tipificadas condutas comissivas e omissivas.

IV. O art. 28 da Lei de Contravenções Penais

A objetividade jurídica é a incolumidade pública, provocada por situação de perigo que possa ser causado a um número indeterminado de pessoas.

A conduta prevista é a de efetuar disparo de arma de fogo em lugar habitado ou em suas adjacências, em via pública ou em direção a ela.

Se o disparo for efetuado em direção a uma pessoa ou a um grupo, teremos uma tipificação remetida ao Código Penal, no caso de tentativa de homicídio ou perigo para a vida ou saúde de outrém.

No parágrafo único a legislação é abrangente a outros fatos perigosos, sem licença da autoridade.

Em sede jurisprudencial, trazemos à colação os seguintes julgados: 
"O perigo decorrente de disparo de arma de fogo em via pública ou em lugar habitado é presumido jures et de jure. Não importa, pois, que tenha sido feito somente para intimidar, bastando a voluntariedade do ato" (RT 435/360).

"Não representa risco para a incolumidade pública e, portanto não configura a contravenção de disparo de arma de fogo, o tiro desfechado no interior de uma casa para o alto" (RT 304/489).

"Infringe o art. 28 da LCP, aquele que dispara arma de fogo contra onibus de passageiros" (RT 236/328).

V. A Lei do Registro e do Porte de Arma de Fogo

Recentemente sancionada a Lei n. 9.437/97, compõe-se de cinco capítulos e um anexo, assim distribuídos:

Capítulo I Do Sistema Nacional de Armas;

Capítulo II - Do Registro;

Capítulo III Do Porte;

Capítulo IV Do Crime e das Penas;

Capítulo V Disposições Finais.

Da simples observação do quadro acima, conclui-se que os três primeiros capítulos, tratam de normas administrativas e explicativas, assim como o último e o terceiro contêm normas incriminadoras.

No capítulo I, composto de dois artigos, o legislador criou o Sistema Nacional de Armas - Sinarm, vinculado ao Ministério da Justiça, dentro do Departamento de Polícia Federal, que é instituição do mesmo Ministério, com circunscrição em todo território nacional, como se depreende da leitura do art. 1".

É de se salientar que merece encômios a posição adotada, mesmo porque a exemplo da identificação civil, prevista na Constituição Federal (art. 5", Inciso LVIII), e por delegação efetuada nos Estados da Federação, pela Polícia Civil, o Departamento de Polícia Federal possui o Instituto Nacional de Identificação (INI), onde se encontram os arquivos criminais de todo o País, visto que às unidades administrativas estaduais, cumpre sempre comunicar todos os indiciamentos e decisões judiciais criminais àquele Instituto, por preceito definido na legislação processual penal (art. 809). 
Destarte, é de suma importância que o Ministério da Justiça, em última instância, o segundo escalão do Poder Civil, dentro do Executivo, tenha ciência de pronto do número de armas e outros dados específicos, em poder da população civil, nos oito milhões de quilômetros quadrados, que constituem a base geográfica nacional.

Convém anotar ainda que o órgão do Poder Executivo, que representa o Ministério da Justiça, em todos os Estados é o Departamento de Polícia Federal, com as Superintendências Regionais, em todas as capitais, incluindo o Distrito Federal, Divisões da Polícia Federal nas cidades de médio porte como: Santos, Ilhéus, Foz do Iguaçu, apenas para exemplificar e as Delegacias de Polícia Federal, nos mais distantes rincões fronteiriços, como: Guajará-Mirim (RO), Tabatinga (AM), e Santana do Livramento (RS), portanto "ratione materiae", cremos sem dúvida alguma tratar-se do órgão certo para a função certa, parafraseando Shakespeare, em uma de sua obras.

$\mathrm{O}$ art. $2^{\circ}$, estabelece as funções que competem ao Sinarm, que assim comentamos, articuladamente:

I. a identificação das características das armas e seus proprietários, é tão necessária quanto à identificação e propriedade de veículos automotores, aeronaves e similares, através de um sistema de cadastro, logicamente com técnicas da moderna informática, possibilitando fácil acesso e rápido atendimento ao usuário;

II. com toda evidência as empresas que produzem armas de fogo tais como a Taurus, Rossi, em âmbito nacional, as empresas estrangeiras fabricantes do revólver Smith \& Wesson, da pistola semiautomática Glock, da pistola semi-automática Beretta, dos revólveres do tipo "Magnum" ora fabricados em nosso País, devem comunicar suas produções e vendas, assim como as lojas revendedoras devem fazer, por sua vez, as devidas comunicações e o fazem através do Registro, que veremos adiante. Com essa providência é fácil se notar que a arma de fogo tem seu acompanhamento desde a produção até o consumidor, assim entendido em termos legais;

III. o ordenamento contido neste Inciso, visa manter atualizados os dados cadastrais antes registrados, posto que em se verificando transferências de propriedade, furto, roubo e outras ocorrências, logicamente altera-se o contido no banco de dados (Date Control Bank, dos americanos), podendo surgir dúvidas acerca de outros crimes, especialmente o homicídio que por valorização jurídico-penal deve ser priorizado em sua apuração;

IV. no que tange às modificações que alterem as características, por exemplo a cromação de uma arma de fogo oxidada, a substituição de um cabo de madeira por um cabo madrepérola, não existem problemas no tocante a seu 
funcionamento.Todavia, o encurtamento de cano (serra), o uso de silenciador (para amortecer estampidos, o alongamento de cano ou troca (para permitir uma melhor pontaria ou precisão de tiro), o uso de "miras telescópicas", que permite um tiro de precisão, normalmente utilizado em competições, são dados que interessam sobremaneira ao Governo, até em termos de segurança nacional, haja vista o "potencial de fogo" que possuem os chamados "cartéis de drogas" que não se circunscrevem mais aos países vizinhos, dado o caráter transnacional deste tipo de delito, e ademais tratamos nesta lei de armas de fogo para uso de civis, em situação de defesa, como explicitado nos arts. 23 e 25 do Código Penal (legítima defesa) e não no uso de armas de fogo para o cometimento de crimes de qualquer natureza. Finalizando este comentário o inciso é altamente positivo, principalmente no campo da Criminalística;

V. por medida de economia, evitando-se gastos supérfluos na administração, como princípio erigido no art. 37 da Constituição Federal e no Regime Jurídico dos Servidores Públicos, devem ser aproveitados os registros atuais, fazendose as respectivas inserções no banco de dados do Sinarm, com os critérios de praxe, isto é não simplesmente despejar os dados existentes, mas criteriosamente colhendoos, selecionando-os, confirmando-os e finalmente alimentando o cadastro, para que não nasça obsoleto ou eivado de vícios que se perpetuam se não extirpados a tempo;

VI. é interessante o cadastramento das armas das armas de fogo, produtos das meras apreensões administrativas (falta de nota fiscal, porte em local não-permitido e outras situações fáticas), em que não ocorre crime, especialmente os constantes no art. 10 desta Lei, que deve ser usado energicamente, tendo-se assim um perfil do portador da arma, que, digamos por qualquer motivo, esqueceu de renovar a autorização, sem contudo apresentar qualquer violação legal no período.

Por outro lado é salutar o cadastramento de armas vinculadas a procedimentos policiais e processos judiciais (quer de natureza civil, como inventários, falências, quanto nos de natureza criminal), para conforme já dito anteriormente ser possível um rastreamento rápido e eficaz do paradeiro da arma e também para que esta não venha a se constituir num futuro "álibi"

O parágrafo único excetua de registro as armas de fogo das Forças Armadas e Auxiliares, por motivos óbvios; em primeiro lugar por serem responsáveis pela segurança interna e externa da Nação, como órgãos originários e as Polícias, aqui, inclusive, a Polícia Militar, por discordar há muito tempo de tal nomenclatura, como órgãos derivados no que diz respeito à segurança pública.

No Capítulo II, vamos encontrar disposições normativas explicativas 
quanto aos deveres do cidadão perante o órgão oficial, bem como seus direitos, estabelecidos em três artigos que comentamos em seguida, referindo-se os mesmos, ao registro de arma de fogo, ao certificado de registro de arma de fogo e ao prazo para regularização de tais bens.

$\mathrm{O}$ art. 3" é norma cogente no sentido de registrarem-se as armas de fogo nos órgãos competentes, ou seja, atualmente nos departamentos das Polícias Civis estaduais em convênio estabelecido com a União, mediante regulamento.Este registro é feito normalmente ao se adquirir uma arma de fogo nos estabelecimentos comerciais credenciados, que somente podem fazer a tradição da arma ao adquirente, após o devido registro, que não deve ser confundido com o Porte de Arma de Fogo, como veremos mais adiante.O artigo em seu caput excetua as armas consideradas obsoletas, quais sejam as meramente usadas como decoração, desde que inservíveis para o uso nocivo (como por exemplo um arcabuz).

No parágrafo único estabelece a lei o dever de registro para os proprietários de armas de fogo de uso proibido ou restrito, que são armas de uso exclusivo das Forças Armadas (fuzil AR-15, por exemplo), os quais promoverão suas inscrições como atiradores, colecionadores ou caçadores no Ministério do Exército, que controla através de órgão próprio, o posicionamento quantitativo, qualitativo e operacional de material bélico em todo o país.

$\mathrm{O}$ art. $4^{\circ}$, normatiza a validade do respectivo Certificado de Registro de Porte de Arma de Fogo, em todo o território nacional, o que anteriormente não ocorria em razão de sua expedição ser através de órgãos estaduais, e por vezes nas mudanças residenciais ou domiciliares, não serem coonestados os atos de autoridades de outros Estados onde anteriormente residia o proprietário da arma de fogo.

Um aspecto importante é a autorização para a mantença da arma de fogo, no interior de instalações de pessoa jurídica (empresa ou estabelecimento), desde que o proprietário da arma seja titular ou seu representante legal. Neste passo é de se indagar se a pessoa jurídica composta de vários diretores, poderão estes fazer o uso do benefício legal em apreço? A questão poderá gerar controvérsias, mas entendemos que se o contrato social, regularmente registrado na Junta Comercial, estipular como responsáveis solidários todos os seus diretores, não haverá óbice a tal prerrogativa, entretanto se esta não for a disposição cremos que somente aqueles ali mencionados (no contrato) é que terão a titularidade e a responsabilidade legal da pessoa jurídica, aliás como aplicado nos denominados "crimes do colarinho branco" (contra o sistema financeiro e tributário, “verbi gratia”). Fora isso, não vemos outra forma de serem absorvidos por essa norma, 
especialmente os denominados "gerentes" a não ser que exista em seu contrato de trabalho, cláusula expressa sobre a responsabilidade legal do estabelecimento ou a empresa, assim consideradas como pessoas jurídicas de Direito Privado.

E que dizer das pessoas jurídicas de Direito Público, que também possuem um titular (Incra, Secretaria do Meio Ambiente, Ibama), podem valer-se da norma ou não? Com toda a propriedade é nosso entendimento que podem, uma vez que não infrinjam normas estatutárias dos órgãos respectivos, ou sejam as denominadas "interna corporis"(portarias, resoluções, avisos).

Outro detalhe, que não pode passar desapercebido, é que o proprietário deve manter a arma de fogo exclusivamente no interior de sua residência ou dependência desta, o que faz o intérprete distinguir, como no Direito Civil, as várias residências que comitantemente pode ter esse proprietário, vez que o domicílio é onde reside com ânimo definitivo, assim entendido o centro de suas atividades principais.

Condicionada à autorização do Sinarm a expedição do Certificado do Registro de Arma de Fogo, como descrito no parágrafo único, evidentemente torna mais segura a funcionalidade do documento, para os objetivos visados pelo legislador, bem como facilitando o usuário em seus deslocamentos pelo País. No art. $5^{\circ}$ é concedida uma espécie de anistia aos proprietários, possuidores e detentores de armas de fogo, que não tenham o respectivo registro. Poderão fazê-lo dentro de seis meses, com igual prazo de prorrogação, a critério do Executivo, presumindo-se a boa fé daqueles que assim agirem, como está escrito no parágrafo único.

$\mathrm{Na}$ verdade, pensamos que o legislador a exemplo dos estrangeiros clandestinos ou irregulares no País, houve por bem permitir que as pessoas de boa índole, que muitas vezes guardam como lembrança arma de fogo pertencente a um antepassado, não viessem a ser surpreendidas com a nova legislação, outorgando-lhes um interregno para proverem a regularização, o que entendemos de bom senso e perfeita consonância com as necessidades da coletividade, que prescinde do combate à marginalidade e não aos homens de bem. Todos nós sabemos que no Brasil de antanho, eram dificultosos os registros, quer de imóveis, pessoas e imaginem armas de fogo; por isso levando-se para um aspecto do Direito Humanitário, o legislador entendeu de relevar essa dose sentimental, dispensando a comprovação de origem da arma, mediante requerimento.

No capítulo III, encontramos a matéria que define a licitude do porte de arma de fogo, em quatro artigos, ora alinhavados.

$\mathrm{O}$ art. $6^{\prime \prime}$ condiciona o porte de arma de fogo à autorização da autoridade 
competente, aliás como previsto desde o tempo imperial (Lei de 26/10/1831), combinada com o art. 297 do Código Criminal do Império, legislação essa reproduzida no Código Penal de 1890, até se transformar no art. 19 da Lei das Contravenções Penais, em 194I, se bem que ocorreram outras legislações a respeito.'

Com efeito, conjugando-se os arts. 6"e 7" da Lei em comento, vê-se que o ato administrativo que autoriza o porte de arma de fogo, é de natureza vinculada e não discricionária, posto que deverão ser observados os seguintes requisitos:

a. o requerente deverá comprovar idoneidade assim entendida a sua convivência social, sua aversão para a prática de condutas ilícitas e evidentemente bons costumes;

b. comportamento social produtivo, vem a ser a pessoa que trabalha e produz de forma benéfica para a sociedade, e não aquele que vive na ociosidade, conhecido o adágio "cabeça de vagabundo é oficina do diabo";

c. a efetiva necessidade visa a espancar o modismo, a imitação que por vezes pode levar a situações indesejáveis e desagradáveis, mormente aqueles que não precisam sequer possuir uma arma de fogo e deveriam até melhor empregar suas economias, eis que não transportam valores, não ocupam posições de destaque onde podem ser alvos de seqüestros ou de ações constrangedoras e até roubos, pois neste caso, outro adágio é cabível: "que se vão os anéis mas que fiquem os dedos";

d. a capacidade técnica é essencial, pois não é concebível que uma pessoa com elevado potencial ofensivo, especialmente contra a vida, não saiba controlar uma arma de fogo, no que diz respeito ao manuseio (limpeza, conservação e desmontagem) e até mesmo o porte (na cintura, axilar, nos membros inferiores), assim como controle emocional para o seu saque, isto é o ato posterior ao porte da arma de fogo, haja vista que o momento do saque para o uso é onde se estabelece o início do nexo causal da conduta, que poderá ser lícita ou ilícita, adequada ou não socialmente e ainda perigosa bilateralmente, tanto para o que saca quanto para o que está na iminência de sofrer uma agressão. Este ponto é crucial no assunto referente a porte com uso de arma de fogo ou qualquer outra arma. Sem qualquer presunção pessimista, mas com os olhos voltados para a causuística, trata-se de um perigo latente.

No $\S 1^{\varrho}$, é limitada a base territorial da licença concedida, circunscrevendo-a ao respectivo Estado, onde o requerente é domiciliado e não-

1. Pimentel, Manoel Pedro. Contravenções Penais Editora Revista dos Tribunais São Paulo 1975 , p. 111. 
residente, pois em alguns casos os locais divergem, especialmente quando a pessoa mora em um Estado e trabalha em outro, retornando a seu domicílio somente nos finais de semana ou até diariamente, como o exemplo de cidades limítrofes: Nanuque (MG), Aimorés (ES) e Serra dos Aimorés (BA) que são contíguas. Atualmente a legislação é no mesmo sentido para que não se tire a autonomia estatal, derivada da soberania da União, havendo a possibilidade de reconhecimento recíproco desde que haja convênio.

Os $\$ \S 2^{\circ}$ e $3^{\circ}$ do Projeto inicial (Projeto de Lei n. 7.865/86 - ns. 64/69, do Senado Federal), foram vetados pelo Chefe do Executivo, que em suas razões afirmou que a "proposição visa reduzir a quantidade de armas de fogo em circulação" e as Autoridades ali referidas e as Forças Armadas e Polícias Militares já possuem legialação própria.

No art. $8^{\circ}$, estipula-se a possibilidade de expedição de autorização federal para o porte de arma de fogo, que difere da estabelecida no $\S 1^{\circ} \underline{\circ}$ por ser de âmbito nacional.Tal autorização obedecerá a exigências especiais, v.g., a necessidade de deslocamentos constantes entre as várias unidades da Federação, transportando valores e/ou documentos, missões de alto interesse comercial, exercício de funções de gestões e administração e assịm por diante.

Os custos operacionais para a expedição da autorização federal para o porte de arma, finalmente vem a ser devidamente compensado, mediante o pagamento de taxa, no valor de $\mathrm{R} \$ 650,00$ (seiscentos e cinqüienta reais), constantes do anexo, o que é providência salutar até então inexistente, para que a União mantenha o Sinarm, nos mais elevados padrões mundiais e também para que se coibam pedidos infundados, por mero diletantismo ou por avareza; anteriormente era grátis, em razão do porte de arma de fogo não ser essencial para a vida humana, muito pelo contrário é altamente nocivo.

Prosseguindo em nossa análise, abordaremos o Capítulo IV, que trata dos Crimes e das Penas referentes a condutas ligadas às armas de fogo, como é de ser visto no art. $10^{\circ}$, composto de quatro parágrafos, além do caput, contendo os $\$ \S 1^{\circ} \mathrm{e}$ e $3^{\circ}$, três e quatro incisos, respectivamente abaixo declinados.

Foi uma grande inovação no campo penal, há muito esperada que veio finalmente criminalizar ações que prejudicam ou põem em risco a população, inclusive deseducando-a.

O caput do art. $10^{\varrho}$ apresenta nada menos que dezoito ações físicas, guardando similaridade com o art. 12 da Lei n. 6.368/76 (Lei de Entorpecentes). 
Passemos a interpretar as referidas ações físicas:

Possuir - significa ter posse ou propriedade de arma de fogo;

Deter - significa o mesmo que segurar indevidamente;

Portar - uma das principais ações físicas, pode ser interpretada como ter à mão para pronto uso, trazer consigo para pronto uso da arma de fogo, como diz a mais abalizada doutrina; ${ }^{2}$

Fabricar - é o mesmo que confeccionar, manufaturar arma de fogo;

Adquirir - é o ato de comprar, obter mediante pagamento arma de fogo;

Vender - é o ato de comércio onde o vendedor transfere a propriedade e por conseguinte a posse da arma de fogo;

Alugar - é o ato de locação mediante pagamento para uso temporário da arma de fogo;

Expor à venda ou fornecer - trata-se de ação física alternativa, em que no primeiro momento a arma de fogo é exposta ao público em uma vitrina por exemplo e no segundo é fornecida como mera relação comercial entre fornecedor e revendedor;

Receber - é o ato de tradição caracterizado pela entrega da arma de fogo a um recebedor, seja por crédito ou por outro fim;

Ter em depósito - é o mesmo que armazenar arma de fogo, digamos um arsenal, guardadas as devidas proporções;

Transportar - é o mesmo que levar de um lugar a outro evidentemente em local público arma de fogo;

Ceder - é o ato de cessão de arma de fogo, sem ônus para o cessionário, visto a locução "ainda que gratuitamente", posto que a cessão com ônus pode ser confundida com o aluguel;

Emprestar - é o ato de empréstimo, da arma de fogo, podendo ser oneroso ou não;

Remeter - é o mesmo que enviar;

Empregar - é o mesmo que usar para determinado fim;

Manter sob guarda - é o mesmo que tomar conta de arma de fogo;

Ocultar é esconder mediante artifício ou ardil, ou até mesmo sem qualquer destes expedientes a arma de fogo da autoridade competente.

Todas estas ações físicas se referem a armas de fogo, de uso permitido, não

2. Pimentel, Manocl Pedro - Contravenções Penais - Editora Revista dos Tribunais - São Paulo 1975 - p. 122 c 123. 
possuindo autorização dos arts. 3e e 6" da Lei e em regulamento previsto no art. 19, do mesmo diploma legal, donde pode concluir-se que a lei referida é norma penal em branco.

A objetividade jurídica que pretende tutelar-se é preventivamente a vida, a integridade física e a saúde da pessoa humana, no intuito de colocar-se obstáculos cada vez maiores à proliferação do uso indevido de armas de fogo.

O sujeito ativo do crime é qualquer pessoa que pratique uma das condutas descritas. Importante é o ensinamento do saudoso e pranteado professor Manoel Pedro Pimentel, "verbis": "E não estamos longe do dia em que o Direito Penal se verá obrigado a reconhecer a pessoa jurídica como sujeito ativo de crime...Por isso mesmo é que vimos sugerindo a elevação das penas acessórias à categoria de penas principais, preparando-se o terreno para o Direito Penal do futuro..."(Contravenções Penais Editora RT - 1975 - p. 103).

Entendemos que muitas das ações físicas podem ser praticadas por pessoas juridicas especialmente e com muito vigor nos dias atuais, no campo dos "importados", como na previsão do $§ 2^{\circ}$, ao tratar de contrabando ou descaminho, sem falar nas empresas de vigilância ou segurança bancária.

Em recente artigo no jornal $O$ Estado de $S$. Paulo, o professor José Eduardo Faria, assim se manifesta: "acima de tudo o ensino juridico se destaca pelo envelhecimento de seus esquemas cognitivos e pelo esgotamento de seus paradigmas. Por isso ele se tornou incapaz de identificar e compreender a extrema heterogeneidade dos novos conflitos...Na prática, contudo, a crescente complexidade da sociedade contemporânea vem tornando inviáveis os mecanismos jurídicos de controle e direção baseados na rígida dicotomia entre o constitucional e o inconstitucional, o legal e o ilegal." ("Saldo Trágico" O Estado de S. Paulo - 02/05/97 - p. A2).

O sujeito passivo no crime em tela é o Estado, posto que como garantidor da segurança pessoal de seus cidadãos, constantemente tem sua função violada pela prática das condutas incriminadas, procurando através da legislação prevenir o mal maior.

Tratam-se de infrações de mera conduta, isto é se perfazem com a simples ação, independentemente de resultado, por se tratar de crimes de perigo.

Devemos ter presente o elemento normativo do tipo, consubstanciado na expressão "sem autorização" ou "em desacordo com determinação legal ou regulamentar", que caracteriza a clandestinidade. ${ }^{3}$

3. Magalhães Noronha, chama à violação da disposição legal ou regulamentar como clandestinidade, csclarecendo que o que a lci incrimina $\dot{c}$ a conduta indevida c abusiva... (Dircito Penal - Saraiva) 
Trata-se de delito de ação múltipla ou conteúdo variável, portanto a prática de uma das ações previstas, como vender e remeter, deve ser considerada apenas uma violação legal.

O elemento subjetivo é o dolo genérico, no sentido da prática de qualquer das condutas previstas no caput, bem como nos parágrafos do art. $10^{2}$.

É admissivel a tentativa nas condutas previstas como fabricar, adquirir, vender, fornecer, ter em depósito, transportar, remeter, empregar e ocultar arma de fogo, de uso permitido, sem autorização e em desacordo com determinação legal ou regulamentar.

A consumação se verifica com a efetiva realização dos diversos núcleos previstos no caput, ein algumas hipóteses independentemente de resultado, como no caso de porte arma de fogo, por ser de mera conduta, onde não é admissível a tentativa.

O concurso de pessoas, como previsto no art. 29 do Código Penal, é cabivel, nas condutas de cunho material, havendo até condutas de concurso necessário, como adquirir, vender, emprestar, porém outras por se tratarem de crimes de mão própria, v.g., portar arma de fogo, evidentemente não admite concurso de pessoas.

É possível também o concurso de crimes como estabelecido nos arts. 69 a 71, do Código Penal.

A sanção prevista para tais condutas é a detenção de um a dois anos, portanto afiançável nos termos dos arts. 321 e ss., do Código de Processo Penal.

$\mathrm{O} \S 1^{\circ}$, estabelece em seus três primeiros incisos condutas que se incluem nas penas do caput, quais sejam:

I. trata-se de conduta omissiva na inobservância de cautelas necessárias, possibilitando que menor de 18 anos ou deficiente mental se apodere de arma de fogo de que tem a posse ou propriedade. O tipo já era previsto no $\S 2^{\mathrm{a}}$ do art. 19 da Lei das Contravenções Penais, e agora foi elevado à categoria de crime, aliás com muito acerto, dado os últimos acontecimentos noticiados. Abre-se exceção para prática de desporto, devendo o menor ser acompanhado por instrutor ou responsável;

II. a situação prevista neste inciso, foi objeto da Súmula n. 174, do Pretório Excelso, no sentido de tipificar o delito de roubo com o uso de "arma de brinquedo" Note-se que existem simulacros que atemorizam de tal forma a pessoa, que podem levá-la à morte e não é justo que o delinqüente transfigurado de inocente ou "bonzinho" apresente-se à Justiça, alegando brincadeira "de índio e mocinho", como no velho oeste, pois a conjuntura atual é bem diferente!!! O dolo é específico, dada a locução 
final, no mesmo sentido do delito capitulado no art. 288, do Código Penal (Quadrilha ou Bando);

III. neste inciso está abarcada a contravenção penal prevista no art. 28 (disparo de arma de fogo), que de igual forma passa a ser crime. O elemento subjetivo sem dúvida é o dolo genérico, isto é a vontade livre e consciente de disparar arma de fogo em local ou via pública ou em sua direção, em local habitado em suas adjacências desde que o fato não constitua crime mais grave, donde seu caráter de subsidiariedade.

$\mathrm{O} \S 2^{\mathrm{S}}$ agrava a pena que passa a ser qualitativamente mais severa, isto é de detenção para reclusão, nos mesmos limites ( 2 a 4 anos) e multa, sem prejuizo de eventual concurso com os crimes de contrabando ou descaminho, bem como se a arma de fogo ou acessórios forem de uso proibido ou restrito, devendo ser verificados os calibres, silenciadores, espécies de visores ou "miras" e assim por diante.

Segundo levantamento da ONU a ser divulgado neste ano, o tráfico e o contrabando de armas são punidos em diversos países com penas gravíssimas, tendo como exemplos: a Grécia, Eslováquia, África do Sul e Vietnã, 20 anos de prisão, portanto cinco vezes mais que em nossa legislação em sua máxima previsão. Outros países prevêem a prisão perpétua, como a China, Índia, Japão, Jamaica e Uganda e em Singapura, a pena de morte.

Portanto, não há o que reclamar como é visto amiúde em comentários jurídicos, sobre a eficácia da lei, sobre sua técnica e outra críticas contumazes, o importante é aplicar a lei, verificando o lado interessante e não "amaldiçoando a escuridão ao invés de acender uma luz"

$\mathrm{O} \S 3^{3}$ estabelece condutas que merecem a pena agravada como descritas no $\S 2^{\mathfrak{s}}$, a saber:

I. trata das supressões ou alterações de marca, numeração ou sinal de identificação de arma de fogo ou artefato, fatos estes que impossibilitam ou tornam dificeis a comprovação de uso em crimes à semelhança dos casos que ocorrem com o furto e roubo de veículos;

II. prevê as modificações efetuadas na arma de fogo, visando aumentar seu potencial ofensivo é o chamado "plus" ou "turbo" tornando de uso proibido ou restrito (troca de cano, munição especial);

III. neste inciso são previstos o uso de material explosivo ou incendiário, normalmente usados em pedreiras ou minerações, sem autorização do órgão competente. O dinamite é de alto teor explosivo e requer cuidados técnicos e especializados, em seu emprego, fabricação, detenção ou posse; 
IV. este inciso é de caráter eminentemente individual e é dirigido aos que foram condenados anteriormente pela prática de crimes contra a pessoa (homicídio), contra o patrimônio (roubo) e tráfico ilícito de entorpecentes ou drogas afins (Lei n. 6.368/76), citações feitas apenas para exemplificar. É evidente que tais tipos de criminosos são os que mais se utilizam de tais armas de fogo ou artefatos, com suas organizações criminosas ou crime organizado (Lei n. 9.034/95) e os chamados crimes hediondos (Leis ns. 8.072/90 e 8.930/94), que em nosso pensamento, devem ser vistos em conjunto com a comentada previsão legal deste inciso, mostrando o rigor penal que o legislador pretende manter.

Diga-se de passagem que a importação de armas de fogo é típica de organizações criminosas, isto porque há uma clandestinidade e burla ao Fisco, à Polícia e em muitos casos envolve os próprios agentes da Administração, como já ocorrido.

$\mathrm{O} \S 4^{\Omega}$ prevê o aumento da pena pela metade, caso o sujeito ativo seja funcionário público, o que é muito aceito, pois não se admite "bandido de carteirinha e distintivo" que é no mínimo um covarde, sem condições de praticar seus intuitos desairosos à sociedade por conta própria, mas maculando instituições.

O último capítulo tratado é o V, intitulado Disposições Finais, composto de onze parágrafos, onde se encontram normas explicativas e proibitivas, visando a complementar o disposto nas normas anteriores, particularmente à norma incriminadora, prevista no art. $10^{\circ}$, mola propulsora da lei.

$O$ art. 11 estabelece que serão definidas por propostas do Ministério do Exército, as armas, acessórios ou artefatos de uso proibido ou restrito, cuja disciplina merecerá ato do Chefe do Poder Executivo, in casu o presidente da República.

Já no art. 12 remete-se à legislação pertinente quanto às armas, acessórios ou artefatos de uso restrito ou permitido.

Nestes dois artigos é bem de se ver que o legislador refere-se a armas, donde conclui-se que se tratam das "próprias (ataque e defesa, como exemplo revólveres) e impróprias (foice, machado, ancinho), além das armas brancas usualmente ofensivas (punhal, canivete-punhal, espada, estilete)" como mencionado na obra já citada de Manoel Pedro Pimentel.

No art. 13 são dadas atribuições ao Ministério do Exército no sentido de autorizar e fiscalizar a produção e o comércio de armas de fogo e demais produtos controlados, inclusive o tráfego de armas de fogo de colecionadores, atiradores e caçadores, diga-se de passagem como é feito nos dias atuais. É prevista a exceção com relação ao art. $2^{\underline{D}}$, para que não haja colisão com as atribuições do Sinarm. 
O art. 14 prevê a apreensão das armas encontradas sem registro e/ou sem autorização. Aqui entendemos, que se tratam das meras apreensões administrativas, por hipótese, armas abandonadas em um matagal ou outro local.

Todavia, havendo previsão legal como no art. $10^{\circ}$ que contém múltiplas ações, cremos que deve ser instaurado o procedimento cabível e os fatos levados ao Judiciário, sem prejuízo da elaboração do laudo pericial e o conseqüente envio ao Ministério do Exército para destinação.

$\mathrm{Na}$ verdade as armas de fogo assim localizadas sempre são consideradas suspeitas na técnica policial e devem ser objeto de investigação e não simples procedimento administrativo.

$\mathrm{O}$ art. 15 veda a fabricação, a venda, a comercialização e importação de brinquedos, réplicas e simulacros de armas de fogo, que com estas possam se confundir.

Esta norma visa complementar o $\S 2^{2}$ do art. $10^{\text {s }}$, na modalidade do delito de contrabando ou descaminho (art. 334 do CPB), isto é uma modalidade específica do contrabando, por se tratar de um produto proibido, portanto no que concerne à importação.

Entretanto, abrimos espaço para uma indagação: e no caso de fabricação, venda e comercialização de produtos nacionais? Existe sanção legal prevista? Não encontramos qualquer sanção a não ser as de caráter administrativo que constituem atos discricionários, porque no âmbito penal apenas poderá ser tipificado o delito de desobediência (art. 330 do CPB).

No parágrafo único, estabelece-se norma permissiva para fins de adestramento ou à coleção de usuário autorizado, nas condições fixadas pelo Ministério do Exército.

O art. 16 atribui ao Ministério do Exército a concessão de autorização excepcional para a aquisição de arma de fogo de uso restrito ou proibido e no parágrafo único excetuam-se as aquisições feitas pelos outros Ministérios Militares, ou seja Aeronáutica e Marinha.

$\mathrm{O}$ art. 17, nova atribuição ao Ministério do Exército no sentido de classificar as armas de fogo bem como os produtos controlados e definir as armas de uso proibido ou restrito.

O art. 18 é muito importante por estabelecer vedação ao menor de 21 anos de adquirir arma de fogo.Cumpre ser fiscalizado com energia este dispositivo, mas muito melhor é educar o homem a não adquiri-las fora da necessidade comprovada, para que não se torne como que uma "prótese" no indivíduo que não consegue andar 
desarmado, talvez até por problemas psicológicos, vulgarmente conhecida como "força do hábito"

No art. 19 existe a previsão de ser expedido um regulamento, no prazo de 60 dias, sendo possível o recadastramento geral ou parcial de todas as armas.

Como questão prática, opinamos pelo recadastramento geral, mesmo porque os arquivos existentes por vezes podem estar desatualizados, por motivos diversos: venda, furto, roubo, perda, omissão de comunicação ao órgão competente e até esquecimento!

Nos arts. 20 e 21 , estabeleceu-se a entrada imediata em vigor da legislação ora publicada, exceto o art. 10, que somente entrará em vigor expirado o prazo do art. 5, que pode perdurar por um ano, face à prorrogação ali mencionada, bem assim a revogação das disposições em contrário que vem a ser os arts. 18, 19 e 28 da Lei das Contravenções Penais e regulamentos afins.

É evidente que se trata de legislação de emergência e deve ser dado um prazo à população para que se regularize perante a Administração, que também deve se adaptar para atender aos novos serviços que irá prestar, inclusive, com a reciclagem de seus funcionários para bem e fielmente cumprirem a lei.

\section{Regulamentação da Lei}

O Decreto n. 2.222/97, expedido em 08/05/97 e publicado no Diário Oficial da União, de 09/05/97, regulamentou a Lei n. 9.437/97.

No Capítulo I (arts. 1e $2^{\mathfrak{p}}$ ), disciplina o Sinarm Sistema Nacional de Armas, respeitada a autonomia dos Estados e do Distrito Federal, excetuando-se os registros próprios existentes nas Forças Armadas e Auxiliares.

O Capítulo II (arts. 3a a 12), estabelece normas para o registro de arma de fogo, especificamente quanto à sua obrigatoriedade; dispensando-se as armas consideradas obsoletas; porém exigindo a prévia solicitação para a efetivação da compra da arma, o que somente ocorrerá após a autorização do registro, aliás de vital significação para estancar até "promoções comerciais" para venda de armas de fogo, como ocorrido no lançamento de conhecida pistola semi-automática $(9 \mathrm{~mm})$ em não menos conhecida loja de departamentos da Capital paulista.

Outras disposições deste Capítulo referem-se a registros de armas de fogo de uso restrito ou proibido, inclusive para policiais federais; definindo o titular de estabelecimento e responsável pelo mesmo, tudo através de contrato respectivo; as 
doações, dados do proprietário para registro e obrigações decorrentes (cautelas, comunicações e autorização para transferência).

O Capítulo III (13 a 29) é a pedra angular da nova legislação, visto conter os requisitos para a obtenção do porte de arma de fogo, tanto em nível federal quanto estadual, destacando-se sua pessoalidade, intransferibilidade e possibilidade de cassação.

Outra novidade é a aptidão psicológica para manuseio de arma de fogo, atestada através de laudo próprio, além de capacitação técnica, que de igual forma deverá ser atestada.

No art. 17 veda-se a condução ostensiva de arma de fogo em clubes, estabelecimentos de ensino e locais onde haja aglomeração de pessoas, oportunidade em que mais uma vez demonstra-se o caráter educacional do Direito Penal, visto a sanção prevista no parágrafo único (recolhimento do porte e apreensão da arma, além de outras providências legais pertinentes).

Para garantia de segurança de vôo é terminantemente proibido porte de armas de fogo a bordo de aeronaves de transporte público, excetuando-se casos excepcionais do interesse da ordem pública (arts. 19 e 20), além de proibição de embarque para o Exterior, por questão lógica e reciprocidade da Soberania das Nações, em suas áreas territoriais.

No art. 25, encontramos as obrigações do portador de autorização de porte de arma de fogo, como obrigação de comunicar a mudança de domicílio, comunicação de furto, extravio ou roubo, bem como recuperação da arma, além de condução da licença, sob pena de cassação, prevista no art. 26.

Outras restrições são estabelecidas no uso de armas de fogo por policiais civis e militares e bombeiros militares, que somente poderão portar armas de fogo nos limites das Unidades da Federação onde exercem suas atividades, exceto convênio entre Estados limitrofes.

Deputados federais, senadores poderão obter autorização para porte de arma de fogo, mediante solicitação dos presidentes de suas Casas legislativas feitas ao ministro da Justiça.

Os servidores dos Poderes Legislativos e Judiciário, bem como os da Administração Direta e Indireta, igualmente poderão obter a autorização mediante manifestação de seus titulares e provando a necessidade de uso, em serviço.

O Capítulo IV (arts. 30 e 31), trata de transferência e trânsito da arma de fogo, sempre com autorização e controle dos órgãos competentes: Polícia Federal, 
Ministério do Exército e Polícia Civil, bem como as Forças Armadas e Auxiliares, com seus registros próprios.

O Capítulo V (arts. 32 a 38), estabelece normas para o cadastramento, interligando a Polícia Federal, o Sinarm, o Siscomex e a Receita Federal, no controle da fabricação, comércio, importação, venda e aproveitamento dos acervos já existentes nas repartições policiais.

O Capítulo VI, contém as disposições finais, que em linhas gerais, prevêem o recadastramento pelas Unidades da Federação, caso julgado conveniente e no interesse da segurança pública; prazo para eficácia do porte de arma de fogo, no âmbito da Polícia Federal; designação das autoridades competentes para expedição do porte de arma estadual, pelos governadores; armas de fogo de uso permitido, bem como artefatos e acessórios, como de pequeno potencial ofensivo definidos no Decreto n. 5.5649, de 28/01/65; destinação das armas de fogo apreendidas, além de outras determinações de caráter administrativo.

As armas de fogo destinadas a prova como instrumentos de crime, como previsto no art. $11^{\mathrm{Q}}$ do Código de Processo Penal, acompanharão o inquérito policial, face à ressalva do art. 44 do regulamento.

Deve ser vista com muita atenção esta previsão, posto que com a nova legislação, a maioria das armas serão produtos de crimes e, ainda, serão recolhidas ao Ministério do Exército que não lhes poderá dar destinação pelas razões já expostas, até a decisão judicial a respeito.

O Ministério do Exército fixará a quantidade de armas de fogo que cada cidadão poderá possuir como proprietário, que, no máximo, deverá ser duas em nosso entendimento, pois o contrário não é arma de defesa pessoal, mas sim jocandi animus prenúncio de guerra ou revolução.

Inteligente a criação do Fundo para Aparelhamento e Operacionalização das atividades-fins da Polícia Federal - Funapol, por sabermos que o órgão policial federal, em razão de suas relevantes atribuições constitucionais, precisa ser visto com olhos de satisfação e orgulho do mais humilde ao mais poderoso, cidadão brasileiro, se tal distinção puder ser notada, pois "todos são iguais perante a lei"

VII. Conclusão

Dentre os pontos positivos que consideramos abrangidos pela legislação merecem ser destacados os seguintes:

- o caráter preventivo da norma, eis que elevada à categoria de crime e 
não mera contravenção, o trato com armas de fogo forçosamente levará a população a se precaver de seu uso indiscriminado e por conseguinte, protegendo-a;

- os crimes cometidos com armas de fogo, por motivos fúteis (trânsito e alcoolismo), poderão sofrer uma queda acentuada com a previsão legal, ao menos àqueles que têm consciência dos problemas causados e seus reflexos;

- é estabelecida a necessidade e não ao "modismo" perigoso de portar uma arma de fogo;

- o cidadão que pretender portar uma arma de fogo, refletirá sobre o binômio de sua auto-afirmação ou autodestruição, diferente do marginal que não se preocupa com tal aferição de valores e quiçá um dia poderá dar-se conta de seu modo de vida;

- será reprimido ou ao menos controlado o interesse comercial das indústrias bélicas nacionais e estrangeiras, aliás com intervenção da ONU, conforme notícias recentes;

- o Governo poderá afirmar sua política de não-violência do desarmamento da população;

- o crime organizado e o tráfico internacional de armas e munições deverão sofrer um prejuizo considerável, ao menos em termos financeiros, que é sua maior intenção ou preocupação;

paralelamente à educação do povo, tarefa que também compete ao Direito Penal, como ensina Manoel Pedro Pimentel, é um passo para o ideal de uma população pacífica e fraterna, ao invés de um povo hostil e desumano.

Em recente publicação no Jornal da Tarde (2/5/97), sob o título: "Aumento mundial do uso de armas de fogo alarma a ONU" informa-se sobre a existência de um estudo recomendando sua restrição e regulamentação em todos os países, citando o Brasil, como o primeiro colocado quanto ao número de vítimas de homicídio, suicídio e acidentes provocados por armas de fogo: 26,97 vítimas mortas por 100 mil habitantes, sendo o Japão o último colocado com 0,07 , num contexto de 46 países.

Assim, concluímos esta apresentação, louvando a iniciativa da nova lei que se antecipa à opinião mundial e procura minimizar esta desconfortável e triste posição mostrada no Direito Comparado Aplicado, face à estatística revelada. 
Bibliografia

NOGUEIRA, Paulo Lúcio. Contravenções Penais Controvertidas - São Paulo - Editora Universitária de Direito - 1993.

NORONHA MAGAlHÃES, Edgard. Curso de Direito Penal São Paulo Saraiva - 1972.

PIMENTEL, Manoel Pedro. Legislação Penal Especial - São Paulo Editora Revista dos Tribunais - 1972.

PIMENTEL, Manoel Pedro. Crimes de Mera Conduta - São Paulo - Editora Revista dos Tribunais - 1975 .

PIMENTEL, Manoel Pedro. Contravenções Penais - São Paulo - Editora Revista dos Tribunais - 1975.

SALLES JÚNIOR, Romeu de Almeida. Contravenções Penais - Brasilivros Editora e Distribuidora Ltda. São Paulo - 1980.

Boletim IBCCrim n 51 - fevereiro/97

Boletim da Associação dos Delegados de Polícia do Estado de São Paulo no 26/96 dezembro/96.

Jornal "O Estado de S. Paulo" - art. "Saldo Trágico" de José Eduardo Faria (03/ 05/97).

"Jornal da Tarde" - "Aumento Mundial do uso de armas de fogo alarma a ONU" (02/05/97). 